\title{
Revision and Participation Patterns in Grades 5 and 6 Wiki Writing
}

\author{
CHRISTINE PORTIER, SHELLEY STAGG PETERSON \\ University of Toronto
}

\begin{abstract}
Our study examined middle grade students' participation in wikis during their two-month social studies unit co-taught by two teachers as part of a larger action research project. Using an analysis of 42 grades 5 and 6 students working together in eight wiki writing groups, we report on the frequency and types of revisions they made to collaborativelywritten essays, and the distribution of the workload across group members in each of the wiki groups. Discussion data with 16 students from these wiki groups helps contextualize our analysis.
\end{abstract}

Our findings suggest that given their extended time to write, students revised frequently, making replacements more often than they deleted, added or moved content. Students indicated a willingness to change others' contributions and to have their own contributions revised by others in order to improve the quality of the essays. The majority of their revisions were at the word level, rather than at sentence, paragraph, and wholetext levels. One student in each group contributed significantly more frequently than any other group member. There were no gender or grade patterns in the frequencies or types of contributions that students made to the wikis.

A web application that creates an online environment for collaborative creation, revision and editing of content is called a wiki. Wikis offer opportunities for everyone within a group to contribute and make it possible to include additional sources of information through external links to other web pages and embedded multimedia files (e.g., images, audio and video) (Leuf \& Cunningham, 2001; Nicol, Littlejohn, \& Grierson, 2005). As such, wikis are ideal spaces for fostering collaborative writing in classrooms.

Some research has documented this use of wikis in upper elementary and middle grades classrooms. For example, wikis have served as a collaborative writing environment for elementary students responding to a question about the possibility of a human colony being established on Mars (Pifarré \& Fisher, 2011), and by middle-grade ELL students to create an information brochure for parents about their new school (Mak \& Coniam, 2008). Additionally, elementary teachers have made wikis available as spaces for students to discuss their problem solving approaches in mathematics classes (Lee, 2012). Accessible during and after school hours, wikis provide a forum for continuous collaboration during all stages of the writing process, making possible the "creation of dynamic text which simultaneously represents both the finished product and the process of creating it" (Karasavvidis, 2010, p. 221).

When looking at the activities of students using wikis, some research has shown that many of the changes made by student wiki contributors have included surface 
changes, for example the editing of grammar or spelling, rather than the substantive reworking of ideas (Hughes \& Narayan, 2009; Meishar-Tal \& Gorsky, 2010). There has also been evidence of social loafing (Jackson \& Harkins, 1985), defined as a tendency for group participants to expend less effort when working with a group than they would if they were working alone (Elgort, Smith \& Toland, 2008; Karasavvidis, 2010). We think that wikis offer more potential for online collaboration and substantive revision of writing than has been realized in the research.

We report on research in which we examined grades 5 and 6 students' participation and revisions in a context where writing a research essay on a wiki was the primary learning activity of a two-month social studies unit, co-taught by two classroom teachers, Kyrie and Sara (all names are pseudonyms), in the final term of the school year. This study was a branch of a larger action research project with these two teachers, where they introduced wikis as a forum to engage their middle-grade students in a collaborative research and essay-writing assignment. The two teachers were conscious of research (e.g., McHatton, Farmer, \& Bessette, 2014; Pianta, Belsky, Houts, Morrison \& The National Institute of Child Health and Human Development Early Child Care Research Network, 2007) showing the paucity of opportunities for middle-grade students to work together in small groups in many middle-grade classrooms, and they wanted to create a learning environment where students worked together collaboratively over a period of months. This assignment was part of a social studies unit, that in previous years, their students had completed as pen-and-paper essays.

Action research is "a form of collective self-reflective inquiry undertaken by participants in order to improve ... educational practices, as well as their understanding of these practices" (Kemmis \& McTaggart, 1988. p. 1). Our action research started with practical questions and reflections that evolved from Kyrie's and Sara's everyday classroom practices. For example, in one of our earliest meetings, they noted that several of their students whom they had previously assessed as reluctant writers had responded in writing more frequently when the reading response assignments were moved onto blogs. The teachers wondered if online writing might increase their students' interest in writing in other areas of the curriculum. Kyrie and Sara were also intrigued by the possibility that online projects might enable students to more readily help each other solve problems. They envisioned that a web application would serve as a tool for collaboration and bring the students' ideas together, becoming an integrated part of the curriculum focus, not necessarily the focus itself. In part, through these reflections, Kyrie and Sara decided to implement a wiki-collaboration social studies project with their students.

The two authors of this paper served as mentor-facilitators who worked with Kyrie and Sara to determine how they would implement the new practices. As mentors, we served initially as a 'spring-board' for their new project ideas, and gave suggestions for the direction their project could take and how they might seek out feedback during the implementation process. We also observed the teachers' lessons and the students' interactions and responses, sharing our reflections with Kyrie and Sara and offering suggestions for change. In one of our meetings, they told us that we were helpful in keeping their planning meetings purposeful. As experienced action researchers, we served as facilitators, by listening to the teachers' ideas and helping them identify steps for scaffolding the students' learning. We were able to offer guidance not only about 
possible steps to take when implementing a new idea, but also about ways the teachers could study their own implementation process and reflect on the efficacy of ideas they were trying.

We also served as co-action researchers with Kyrie and Sara, by gathering data to assist the teachers in assessing the impact of their new teaching practices (Capobianco, 2007). We examined the frequency and types of revisions that the grades 5 and 6 students made to their collaboratively written essays, and the distribution of work among group members, so our research informed the two teachers' practices over two years.

The following research questions guided our research: (1) How frequently do students revise their own and others' essay contributions? (2) What types of revisions do students make to their collaboratively written essays? (3) Comparatively, how frequently do individual students and the entire group contribute to each wiki?

\section{Theoretical Approach}

Our research is underpinned by a view of writing as a social practice that embraces linguistically and culturally diverse ways of using language and representational modes, for example through graphic designs and web-based media and print (Coiro, Knobel, Lankshear \& Leu, 2008; Lankshear \& Knobel, 2011). New technologies are a vehicle for creating new communication and social practices where meaning is represented through multiple media, forms and modalities. Internet users have many tools and forms at their disposal to construct meaning. Additionally, digital electronic networked technologies provide new ways to create texts, and expand potential audiences for the texts, and types of audience interactions with the texts (Leu, Kinzer, Coiro, Castek, \& Henry, 2013).

Text production and consumption in a wiki environment are characterized by collaborative participation and distributed expertise (Lankshear \& Knobel, 2011). All wiki text contributors have equal opportunities to add, modify, delete, or reformat text, images and audio material. In turn, all contributions can be changed by others at any time and no one contributor's expertise and authority is valued above another's.

\section{Review of the Literature}

\section{Revision Practices}

Revision is "a fundamental component of the writing process. So fundamental that for some specialists writing is largely a matter of revising" (Allal \& Chanquoy, 2004, p. 1). Fitzgerald (1987) defined revision as "making any change at any point in the writing process. In an effort to improve the writing, revision involves identifying discrepancies between intended text and instantiated text" (p. 484). Revision is a complex problem-solving process that requires a writer's awareness of the audience, sense of the goals for the writing, and ability to critically read the emerging writing by drawing on what is known about language, writing, and the topic at hand (Macarthur, Graham, \& Harris, 2004). Elementary and middle school writers often do not make substantive revisions (Rijlaarsdam, Couzijn, \& Van den Bergh, 2004), as many of them struggle with the complex demands of revision or they are not highly motivated to make the extra effort to improve their texts. Students may also not understand how revision contributes to the 
quality of their writing. In fact, Witte (2013) found that teachers do not always distinguish between revision and editing/proofreading, and do not spend as much time on revision instruction as on instruction for other aspects of the writing process, for example, planning and drafting. In an attempt to foster students' independent revision practices, Dinkins (2014) worked with a classroom teacher who implemented strategy-based instruction for revision. Although her study involved only a small group of eighth-grade students, her findings "support the need for instruction focused on revision" (p. 88).

There is a limited amount of research available that addresses the practices of middle school wiki writers. Based on research conducted with middle school students and with contributors in other areas, such as post secondary students, the following benefits and concerns on wiki writing and revision practices are noted.

\section{Revision Practices on Wikis}

Previous research examining revisions made to wiki writing has led researchers to conclude that the physical ease of revising on computers, and the need to read peers' and one's own writing in order to contribute to a wiki text, are factors that support students in the revision process (Jones, 2008; Kessler, 2009; Mak \& Conium, 2008; Woo, Chu \& Li, 2013). When writing collaboratively on wikis, English Language Learners in postsecondary classrooms (e.g., Kessler, 2009), grade 5 and 6 students (Woo, Chu \& Li, 2013), and contributors to selected Wikipedia pages (Jones, 2008), were found to engage in more content-level than surface-level revisions. With adults enrolled in second language classes, Kost (2011) found that the wiki environment was beneficial to revision behaviours, with students making meaning-changes to the content of their writing such as translating to clarify content or incorporating further ideas into the text. Furthermore, Year 7 ELL students in Mak and Conium's (2008) study used wikis to write longer compositions that were more coherent than those written with pen and paper, though most of their wiki contributions involved the addition of new ideas, rather than revisions of first-draft text.

There are exceptions to these findings, however. Elementary students in Pifarré and Fisher's (2011) research made few changes to the macrostructure of their collaboratively constructed texts, and some undergraduate IT students in Karasavvidis's research (2010) cut and pasted information from websites into their wikis, but did not revise the original content in their own or their peers' writing.

\section{Collaborative Writing on Wikis}

Collaboration is defined by Haythornthwaite (2006) as an equal distribution of the workload among all participants. Wikis offer opportunities for student collaboration, however, previous research has shown that collaborative knowledge construction and text creation are not a given when wikis have been used in classrooms. Hughes and Narayan (2009), for example, found that almost $20 \%$ of postsecondary students contributing to either a key term glossary in an Interactive Design course or an assignment archive in a graduate Learning Technologies seminar had not edited or even read their peers' wiki contributions, much less revised or negotiated changes to peers' writing. Similarly, the Year 7 ELL students in Mak and Coniam's (2008) study, elementary students learning Spanish in Lee's (2010) research, and undergraduate students in Karasavvidis's (2010) 
study, posted new information but did not change wiki information. Interview data revealed that many students felt uncomfortable revising classmates' writing, feeling "anxious that others might not take edits very well" (Karasavvidis, 2010, p. 227) or lacked confidence in their abilities to revise or edit their peers' writing (Lee, 2010). To overcome students' hesitancy to make revisions to collaborative texts, Wichmann and Rummel (2013) gave undergraduate students collaboration scripts and found these were helpful in overcoming this hesitation and led to revisions that improved the coherence quality of their texts. Doult and Walker (2014) found that nine and ten year old students would jointly author several group wiki pages for their collaborative projects, however, there remained one dominant author for these pages, with other students tending to make changes to the original author's words only after being invited to do so or negotiating the changes to be made. It appears that learning activities involving wikis do not "guarantee that individuals will work together as a group" (Elgort, Smith, \& Toland, 2008, p. 207).

\section{Fostering All Students' Participation}

To overcome the challenges posed by collaborative wiki learning environments, teachers participating in previous classroom wiki research drew upon cooperative learning principles (Johnson \& Johnson, 1989, 2009; Slavin, 1996). One principle suggests that the greatest learning effects of cooperative learning occur with the use of interpersonal reward and task structures. Both group goals and individual accountability need to be built into the learning process so that students encourage peers to fully participate (Slavin, 1996). If the learning activity is structured around a group goal, then the students will direct their efforts toward the group's success. However, the activity must also contain some individual accountability so that all members will participate and learn. Rewards are then based on group performance, which in turn is conditional on the learning of each group member. Structured group interactions have become a positive technique associated with cooperative learning, whereby students are directly taught or modeled, often through scaffolded steps, or with cognitive, behaviour or social interaction strategies. Students then reinforce and practice these strategies within their small groups to help each other learn. With the increased access of Web 2.0 tools in classrooms, wikis offer a potential forum for students to work collaboratively. Piezon and Donaldson (2005), for example, observed that students felt a greater sense of accountability for their work when teachers built task interdependence into wiki tasks. In this way, the success of individual students was linked to the success of the group as a whole. Students' relationships with peers can serve to support their learning, as "cognitive engagement is enhanced when class members actively discuss ideas, debate points of view, and critique each other's work" (Fredricks, Blumenfeld, \& Paris, 2004, p. 77). Web 2.0 tools can foster these expanded peer roles and help create exploratory learning environments that appeal to middle grades students and engage them in active and purposeful learning, both important characteristics for effective adolescent education (Association for Middle Level Education, 2010).

\section{Research Methods}

This study was part of a larger action research project that took place over a twoyear period in the middle grades classrooms of a K-6 public school. Over the two years, 
we implemented qualitative methods and this paper reports on the statistical analysis of our inductive coding of the students' wiki-writing revisions and participation. To contextualize this analysis, we include some of the responses from our meetings and discussions with the students where they shared their thinking about collaborative writing on a wiki and what they learned through the process.

\section{School and Participants}

The participating school was located near the downtown core of an urban center in Ontario, Canada. The school serves approximately 380 students from a low to midlevel socio-economic residential neighbourhood. Most of the students attending this school were born in Canada, with a small percentage learning English as their second language.

The participating teachers, Kyrie and Sara, each had between 5 and 10 years of teaching experience. In the first year of our study, Kyrie had 30 grade 6 students and Sara had 28 grade 6 students (equal numbers of girls and boys in each class). The following year, they both had combined grade 5/6 classes: Sara with 30 students and Kyrie with 29 students. In this year there were fewer grade 5 students (25) than grade 6 students (34), and more boys than girls ( 15 boys to 10 girls in grade 5 and 20 boys to 14 girls in grade $6)$. In our discussions with the teachers, they conveyed that their grade 5 and 6 students spanned the range of academic abilities, with a very small group of students (only one included in our data) withdrawn for language and math support in the mornings.

Near the beginning of both school years, the teachers introduced our study to the parents who attended school-wide curriculum night meetings, and they sent consent forms home with all the students. All students returned the consent forms and were given parental permission to participate in this study. To follow the students' collaborative writing processes, we randomly selected and collected data from 8 wiki groups with a total of 44 students ( 4 groups each year; 20 students the first year and 22 students the next year). From this group of students, we randomly asked two students from each group to meet with us to talk about the wikis. These discussions provided a context for the students' writing.

\section{Classroom Instruction and Wiki Writing Context}

The students became familiar with online tools through homework blogs that Kyrie and Sara set up near the start of the school year. The teachers used these blogs to post assignment questions for the students to respond to independently from home, beginning with math questions and then gradually posting questions from other areas of the curriculum. With these blog activities, the students developed confidence and competence when navigating online and posting comments. Following the students' responses to blog activities, the teachers and students often discussed the range of responses posted or used the posted ideas for subsequent activities. For example, in one of the lessons that we observed, the teachers printed copies of the students' blog responses from a social studies homework assignment the previous evening. They had asked the students to select an item that they have at home and identify the country where it was manufactured. Each group of four students was given a set of their peers' printed blog entries and asked to sort the items into categories and list their categorization rules. 
The students tended to sort the items first by the country of manufacturing and then by the item type. When the students finished sorting and discussing their ideas, they regrouped to share their categorization processes. As the students mentioned where their items were produced, the teachers marked a world map to begin a list of countries from which Canada imports goods.

About halfway through the school year, Kyrie and Sara used the free version of a wiki system called PBworks (found at http://www.pbworks.com), to set up several group wikis for a social studies project. They organized a series of short whole-group lessons to guide the students through the wiki navigation features, to show them new online tools, and to introduce them to the new project. The teachers posted information about the social studies project on the front page of the wiki, and from this main page, the students could link to their individual group wikis. Kyrie and Sara provided mini-lessons to model different ways students could search online and identify appropriate age and reading-level material for their projects. They also showed their students how to quickly scan images and text for information that might be relevant to their research topics and how to sort this information into physical, environmental, economic, political and social categories (they referred to these as PEEPS) that would help them organize their research reports. For example, in one of their early lessons about the PEEPS topics, the teachers gave each student a photograph and asked them to tape their photo under one of the PEEPS category headings that they had posted in the hallway (the third floor hallway outside of Kyrie and Sara's classrooms was wide and because there were few other classrooms upstairs, they frequently used this space for lessons). The students grouped themselves by their category choices and engaged in discussions about their decisions. The students regrouped to share the characteristics of each category and then independently wrote about each category, using the images to help with their definitions.

The students' social studies research notes and images, and writing drafts and revisions were organized with the wikis. Time for wiki group writing was assigned during school hours and students were also encouraged to continue the wiki writing at home on their own time. The majority of students had access to computers and the Internet from home, so most after-school participation took place from home. Four to five students in each class did not have home internet access so these students used the school laptops before or after school hours or at recess, when the teachers were available in their classrooms and the school was open.

In each year there were 12 wiki groups and Kyrie and Sara placed 4-6 students into each group based on each student's topic preferences (e.g., littering, homelessness, poverty, child labour). The teachers explained to the students that this project would require them to work from home independently and at school with their wiki group members to research their topics, create notes and organize these notes on the wiki according to the PEEPS connections to their chosen wiki topic. The collaborative notes and final essays were later used in a culminating independent unit assignment. In these independent assignments, students were expected to create a 'book jacket' summarizing the key points about their group's topic using text and drawings/photographs drawn from online sources. This paper presents the data collected during the note-taking and collaborative writing stages of the project.

The two teachers introduced the students to wikis and showed them how to 
navigate through the pages. They modelled steps in taking notes, beginning with how to decide if an online source is appropriate for their age and reading levels, how to scan for their topic information, how to summarize information and then compose a note. They also reviewed and refined these steps in response to the students' needs once the project began. Drawing upon cooperative learning techniques, during their collaborativelyplanned and taught mini-lessons, the teachers provided explicit instruction on how to cooperate with peers, discussed their created group-assessment protocols, and gave feedback on how well students worked together to facilitate a collaborative online environment.

\section{Data Collection}

We see writing as a social practice, so we looked at the social interactions of students within the representational mode of an online forum. We gathered wiki writing data from March to June in the first year and again from March to June of the second year. Although we visited the classrooms several times to observe lessons and student activities and took field notes to document how the teachers prepared students to use the wikis and support their writing development, it is beyond the scope of this paper to report on these findings. For this study, we report on the wiki writing data gathered from the selected eight wiki-groups. The research topics of our focus groups were as follows:

Year 1: Grade 5 - littering; plastic waste

Grade 6-water sanitization; plastic waste

Year 2: Grade 5 - homelessness; polluted water

Grade 6 - plastic waste; poverty

To support our analysis of the essays of the participating wiki groups, we decided to meet with four girls and four boys, two from each of the focus wiki groups in each year of the study. Within these gender and number parameters, we randomly selected students to individually meet with us. At this time we asked the students to share their ideas around their decisions of what to write and revise on their wikis and what they felt they learned from their collaboration on the wikis. We recorded each conversation and, in this paper, we use samples from the larger transcripts of the students' responses to contextualize our analysis of the students' wiki writing and participation.

\section{Data Analysis}

This study was guided by three questions to help us develop some insights into the collaborative writing and revision practices of middle school students using a wiki environment: (1) How frequently do students revise their own and others' essay contributions? (2) What types of revisions do students make to their collaboratively written essays? (3) Comparatively, how frequently do individual students and the entire group contribute to each wiki? These questions were addressed through a statistical analysis of our coding, with individual student discussions serving to contextualize this analysis.

To determine the nature and frequency of students' revisions to the collaboratively written essays (questions 1 and 2), we used the history feature of the wikis 
to print out the daily contributions made by the students in each wiki group. We separated out all the contributions that were not revisions (e.g., note taking, formatting, feedback comments to peers) and then noted the day and time for each revision action and the name of the student(s) who performed the revision (e.g., the group members writing together during the school day or an individual student writing after school hours).

Using the history of contributions for two of the wikis, we developed a list of preliminary codes by identifying what the student's or group's revision involved (e.g., adding words, changing phrases, deleting clauses). We refined our codes through an iterative process, where we read through and coded the two wikis multiple times, discussing any ambiguities, removing, combining or adding codes, and clarifying the descriptions of each one. Then all eight wikis (the first two and the remaining six) were coded by one of the authors using the categories that we developed. Our codes are described with examples in Table 1.

Table 1

Codes Used to Analyze Students’ Revisions

\begin{tabular}{|c|c|c|}
\hline Revision Type & Initial Wording & Revision \\
\hline replaced word & $\begin{array}{l}\text {... more than half of which comes } \\
\text { from plastic packaging }\end{array}$ & $\begin{array}{l}\text { More than half originated } \\
\text { from plastic packaging }\end{array}$ \\
\hline replaced phrase & keep everyone informed & inform everyone \\
\hline replaced clause & $\begin{array}{l}\text {... because they do not have an } \\
\text { education }\end{array}$ & ... they have no schema \\
\hline added word & $\begin{array}{l}\text { Polluted water and fish are not fit } \\
\text { for human consumption. }\end{array}$ & $\begin{array}{l}\text { Polluted water and fish are } \\
\text { not fit for human/animal } \\
\text { consumption }\end{array}$ \\
\hline added phrase & $\begin{array}{l}\text { government's aim is protect } \\
\text { drinking water in lake Ontario }\end{array}$ & $\begin{array}{l}\text { For example, the Ontario } \\
\text { government's aim is to } \\
\text { protect drinking water in lake } \\
\text { Ontario }\end{array}$ \\
\hline added clause & $\begin{array}{l}\text { The Great Lakes have been under } \\
\text { threat for the last two centuries. }\end{array}$ & $\begin{array}{l}\text { The Great Lakes have been } \\
\text { under threat for the last two } \\
\text { centuries but the situation is } \\
\text { the far worse today. }\end{array}$ \\
\hline deleted word & or maybe they ... & Maybe they ... \\
\hline
\end{tabular}




\begin{tabular}{|c|c|c|}
\hline deleted phrase & $\begin{array}{l}\text { politicians have to work hard to } \\
\text { manage and control water pollution } \\
\text { levels through organizations }\end{array}$ & $\begin{array}{l}\text { Politicians have to work hard } \\
\text { to manage and control water } \\
\text { pollution levels }\end{array}$ \\
\hline deleted clause & $\begin{array}{l}\text { you have to tell the people to pick it } \\
\text { up also they all where wearing the } \\
\text { same equipment. }\end{array}$ & $\begin{array}{l}\text { Did you know that you have } \\
\text { to tell the people to pick it } \\
\text { up. }\end{array}$ \\
\hline deleted sentence & $\begin{array}{l}\text { And if it looks like a dump the } \\
\text { tourist get less money. }\end{array}$ & \\
\hline $\begin{array}{l}\text { changed the } \\
\text { order of words }\end{array}$ & $\begin{array}{l}10.6 \text { million died in } 2003 \text { before } \\
\text { they reached the age of } 5 \text { (or about } \\
29,000 \text { children per day) }\end{array}$ & $\begin{array}{l}\text { In } 2003,29000 \text { children died } \\
\text { per day. }\end{array}$ \\
\hline moved word & $\begin{array}{l}\text { Poverty usually increases after a } \\
\text { natural disaster hits a poor area. }\end{array}$ & $\begin{array}{l}\text { Poverty increases usually } \\
\text { after a natural disaster hits a } \\
\text { poor area. }\end{array}$ \\
\hline moved phrase & $\begin{array}{l}\ldots \text { and liquid wood is also called } \\
\text { arboform. }\end{array}$ & $\begin{array}{l}\text { Arboform is also called } \\
\text { liquid wood. }\end{array}$ \\
\hline $\begin{array}{l}\text { divided sentence } \\
\text { into two }\end{array}$ & $\begin{array}{l}\text {... issue polluted water (water } \\
\text { sanitization) as a group ... }\end{array}$ & $\begin{array}{l}\text {... issue polluted water (water } \\
\text { sanitization). As a group ... }\end{array}$ \\
\hline
\end{tabular}

We ran frequencies of each code in each wiki and then used Chi-squared tests for goodness of fit within each wiki in terms of the types of revisions and who made the revision to determine if there were significant differences in the types of revisions and whether the revisions were at the word, phrase or sentence level.

To determine the participation patterns among individuals and groups (question 3 ), we examined all the contributions and not only the revisions. After coding each contribution in terms of who had contributed, we used Chi-squared tests of goodness of fit to determine differences in frequencies of the participation between the group contributing during class time and individuals at home, and between individual students within a wiki group.

\section{Results}

\section{Students' Revisions to Collaboratively-Written Essays}

The average number of revisions to the essays per wiki group was 72, although the range was wide: from 20 revisions in the grade 5 littering group in Year 1 to 222 in the grade 6 plastic waste 2 group in Year 2. Of the three types of revisions that students 
made (replacing, adding, or deleting content), replacing words was the most common type of revision in all of the wikis, with the frequency being significantly higher than other types of revisions in three of the wikis: grade 6 water sanitization, $X^{2}(1, N=43)=$ 3.846, $p<0.001$, grade 6 plastic waste, $X^{2}(1, N=222)=5.453, p<0.001$, and grade 5 plastic waste, $X^{2}(1, N=116)=18.356, p<0.05$, in Year 1 (see Table 2). Students made fewer deletions than additions and replacements of information, except in three wikis, littering, plastic waste, and homelessness, which had more deletions than additions. Across all wikis, revisions made to the collaboratively-written research essays were more likely to be at the word and phrase levels than at the more substantive sentence and paragraph levels.

Table 2

Revisions Made to Research Essays on the Wiki (Percentages)

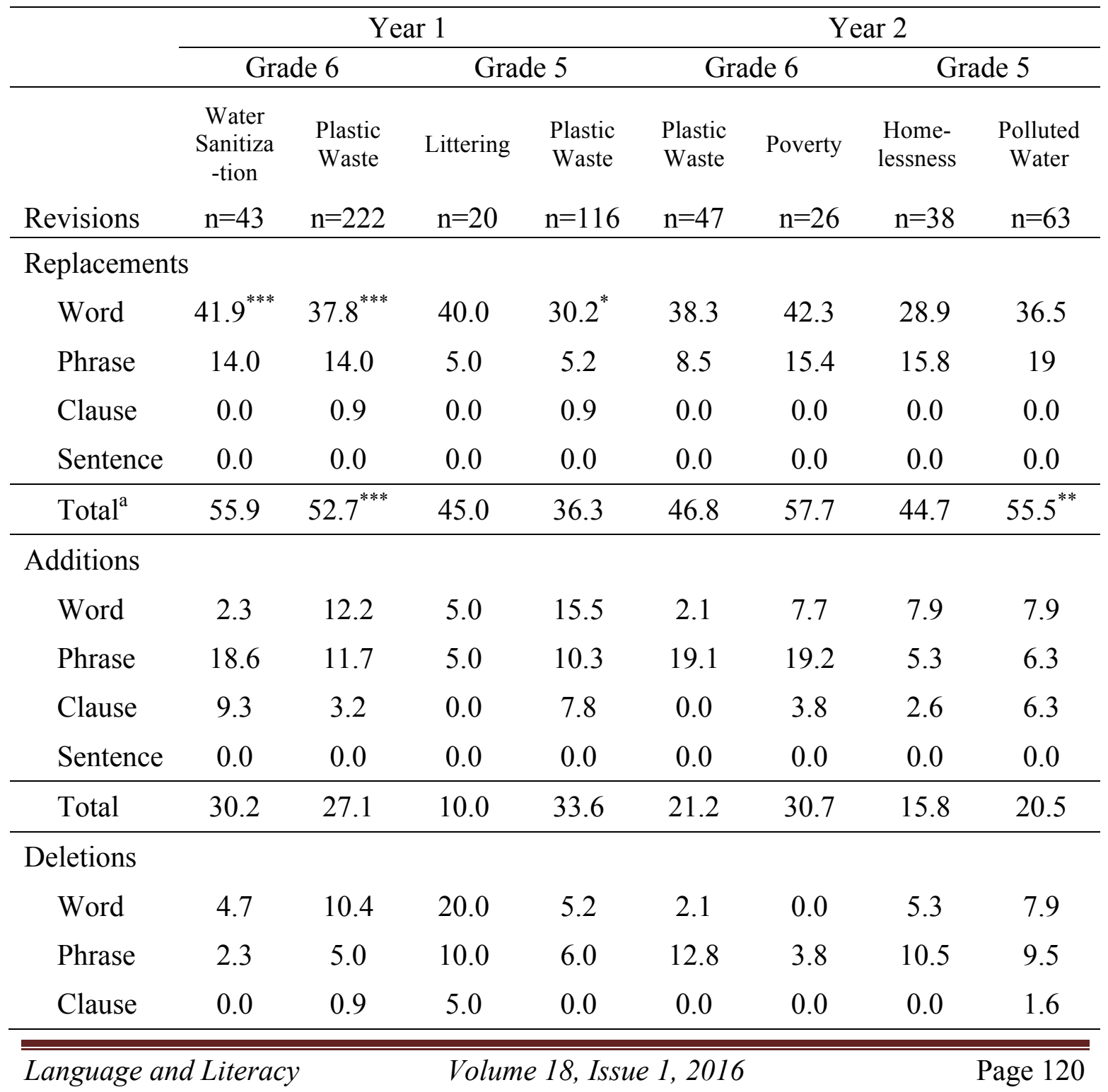




\begin{tabular}{lcccccccc}
\hline Sentence & 2.3 & 1.8 & 10.0 & 11.2 & 10.6 & 0.0 & 15.8 & 0.0 \\
\hline Total & 9.3 & 18.1 & 45.0 & 22.4 & 25.5 & 3.8 & 31.6 & 19 \\
\hline Moves & & & & & & & & \\
Word & 0.0 & 0.9 & 0.0 & 0.0 & 2.1 & 3.8 & 0.0 & 1.6 \\
Phrase & 2.3 & 0.0 & 0.0 & 1.7 & 0.0 & 3.8 & 2.6 & 0.0 \\
Sentence & 0.0 & 0.0 & 0.0 & 2.6 & 0.0 & 0.0 & 5.3 & 0.0 \\
Divided & 2.3 & 1.4 & 0.0 & 3.4 & 4.3 & 0.0 & 0.0 & 3.2 \\
sentence & & & & & \\
Total & 4.6 & 2.3 & 0.0 & 7.7 & 6.4 & 7.6 & 7.9 & 4.8 \\
\hline
\end{tabular}

${ }^{\mathrm{a}}$ The totals for the types of revisions (replacements, additions, deletions and moves) were compiled and compared.

${ }^{*} \mathrm{p}<0.05 .{ }^{* *} \mathrm{p}<0.01 .{ }^{* * *} \mathrm{p}<0.001$

Our individual meetings with the students provided information about their rationales for the types of revisions that they made. Some groups negotiated the inclusion or deletion of particular information. As explained by a grade 5 boy, his group members "tried to cross out what [they] didn't like and find a better way to explain it that [they] both agreed on." In a grade 6 group, individual students "crossed out what the other person said when information clashed" with what they were finding. This information clashing sometimes prompted wiki group members to "go out and find other information." Almost all students said that they made changes to a peer's writing and that peers made changes to their own writing. Because the students perceived that they were making the writing better, they felt fairly comfortable making changes to a group members' writing contributions and, for the most part, accepted others' changes to their own writing. In the students' words, these revisions helped to "bump up our ideas" and "boost our grades" for the final written product.

\section{Frequency of Participation in Wiki Collaborative Writing}

Across the wiki groups, there were no gender patterns in the number of contributions that students made independently to their wikis. In the groups with a disproportionate number of boys or girls, the larger gender group contributed significantly more wiki entries than the other: in Year 1, girls in grade 6 plastic waste, $X^{2}$ $(1, N=241)=241.000, p<0.001$, and boys in grade 5 plastic waste, $X^{2}(1, N=160)=$ $148.225, p<0.001$; in Year 2, boys in grade 6 poverty, $X^{2}(1, N=47)=47.000, p<0.001$, and boys in grade 5 homelessness, $X^{2}(1, N=34)=34.000, p<0.001$. An exception occurred in the Year 2 grade 5 polluted water group. In this group of four boys and two girls, a very academically strong girl took on a leadership role so there were significantly more contributions by girls than by boys in this group, $X^{2}(1, N=69)=47.087, p<0.001$. In one of the wiki groups with an equal number of boys and girls, there was no significant gender difference in the number of contributions (Year 1, grade 6 water sanitization). However, the other two groups with an equal number of boys and girls did show an unequal number of gender contributions. In the Year 1 grade 5 littering group, only one 
girl contributed to the wiki independently, $X^{2}(1, N=51)=51.000, p<0.001$. The Year 2 grade 6 plastic waste group also had an equal number of boys and girls yet the girls contributed significantly more often independently than the boys, $X^{2}(1, N=158)=$ 49.013, $p<0.001$ (see Table 3).

Table 3

Independent Contributions Made by Group Members (Percentages)

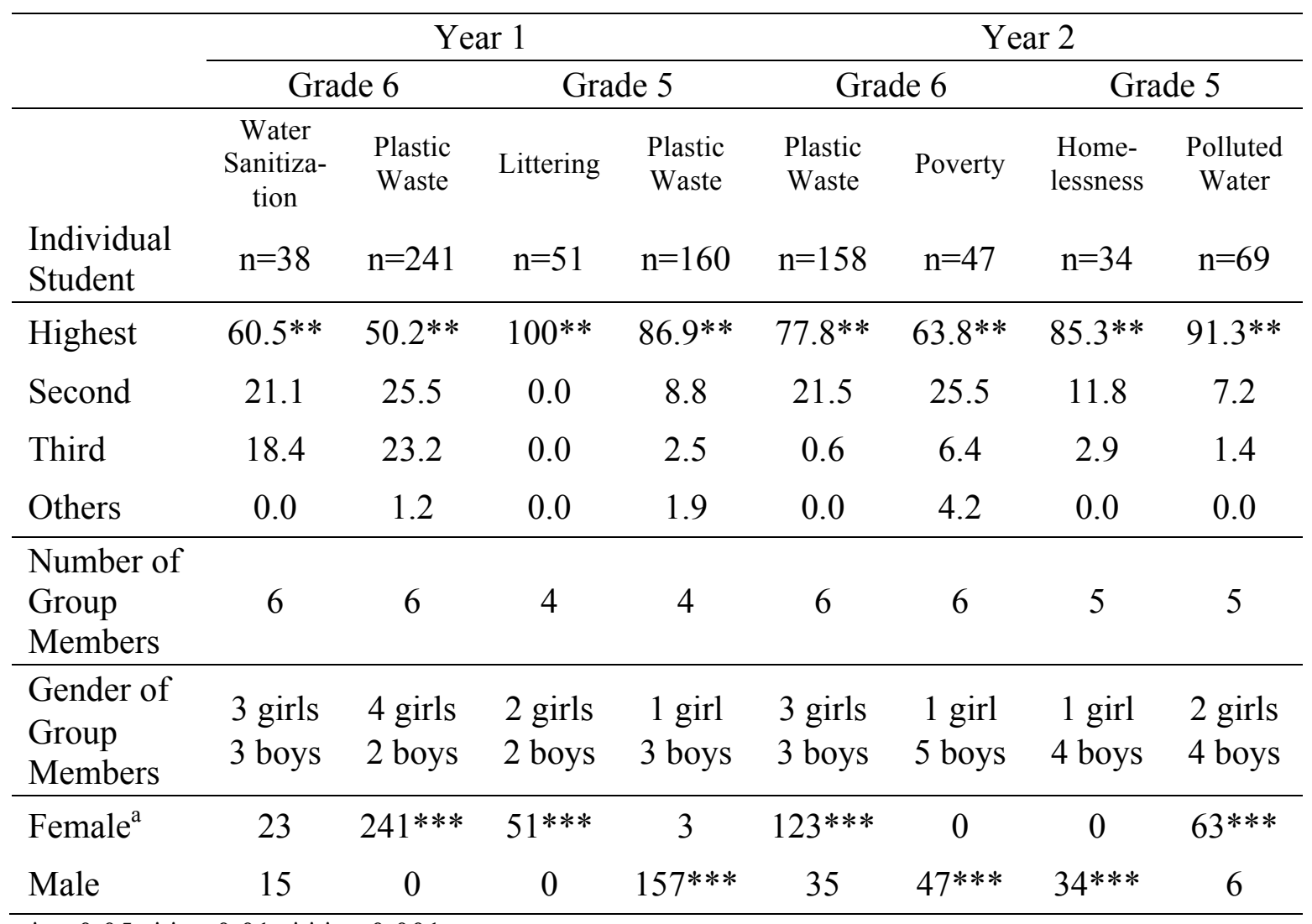

${ }^{*} \mathrm{p}<0.05 . * * \mathrm{p}<0.01 .{ }^{* * *} \mathrm{p}<0.001$

${ }^{a}$ Here the table shows the number of wiki contributions made by female and male students.

In all the grade 5 and grade 6 groups in both years, one member independently contributed to the wiki significantly more often than any other group member. Table 3 shows the percentage of all contributions (including initial addition of content and later revisions) made by the student who contributed most frequently, followed by percentages of contributions by the second and third most frequent contributors. Furthermore, in three wikis, individuals contributed significantly more often to their wikis independently after school hours than their group did together at school: in Year 1, the grade 6 plastic waste group, $X^{2}(1, N=295)=118.539, p<0.001$ and grade 5 plastic waste wiki group, $X^{2}(1, N$ $=245)=22.959, p<0.001$; and in Year 2 , the grade 6 plastic waste group, $X^{2}(1, N=206)$ $=58.738, p<0.001$. 
In three other wikis, the group working together contributed significantly more frequently than individuals did on their own. These include the Year 1 grade 6 water sanitization group, $X^{2}(1, N=104)=7.538, p<0.01$, and the Year 2 grade 6 poverty group, $X^{2}(1, N=166)=31.229, p<0.001$, and the grade 5 homelessness group, $X^{2}(1, N=$ $141)=37.794, p<0.001$. The remaining two wikis showed close to an equal number of contributions from the group together and individuals on their own (see Table 4).

Table 4

Individual and Group Contributions to Wikis (Percentages)

\begin{tabular}{|c|c|c|c|c|c|c|c|c|}
\hline & \multicolumn{4}{|c|}{ Year 1} & \multicolumn{4}{|c|}{ Year 2} \\
\hline & \multicolumn{2}{|c|}{ Grade 6} & \multicolumn{2}{|c|}{ Grade 5} & \multicolumn{2}{|c|}{ Grade 6} & \multicolumn{2}{|c|}{ Grade 5} \\
\hline & $\begin{array}{c}\text { Water } \\
\text { Sanitization } \\
\mathrm{N}=104\end{array}$ & $\begin{array}{l}\text { Plastic } \\
\text { Waste } \\
\mathrm{N}=295\end{array}$ & $\begin{array}{l}\text { Littering } \\
\mathrm{N}=98\end{array}$ & $\begin{array}{l}\text { Plastic } \\
\text { Waste } \\
\mathrm{N}=245\end{array}$ & $\begin{array}{l}\text { Plastic } \\
\text { Waste } \\
\mathrm{N}=206\end{array}$ & $\begin{array}{l}\text { Poverty } \\
\mathrm{N}=166\end{array}$ & $\begin{array}{l}\text { Home- } \\
\text { lessness } \\
\mathrm{N}=141\end{array}$ & $\begin{array}{c}\text { Polluted } \\
\text { Water } \\
\mathrm{N}=142\end{array}$ \\
\hline $\begin{array}{l}\text { Group } \\
\text { Contributions }\end{array}$ & $63.5^{* *}$ & 18.3 & 48.0 & 34.7 & 23.3 & $71.7^{* * *}$ & $75.9^{* * *}$ & 51.4 \\
\hline $\begin{array}{l}\text { Individual } \\
\text { Contributions }\end{array}$ & 36.5 & $81.7^{* * * *}$ & 52.0 & $65.3^{* * *}$ & $76.7^{\text {**** }}$ & 28.3 & 24.1 & 48.6 \\
\hline
\end{tabular}

Our observation and student-discussion data contextualize these findings. We observed that Kyrie and Sara devoted at least two hours each week for wiki groups to work together during school hours, providing assigned time for group writing. Additionally, they expected students to contribute on their own at home, but did not specify how much homework time students should devote to the wiki writing. A grade 5 girl said that she appreciated sharing the responsibility for various parts of the overall topic: "If I'm doing it on my own, there are some things that I might not know that others might know. We all have a different part and it's like puzzle pieces; they all fit together." All students, however, pointed out inequities in the contributions made by members of their group and talked about the need for "everyone to step up and do the work." Even the students who contributed very little agreed with a grade 6 girl that, "some people don't go on the wiki very much."

\section{Discussion}

Our research findings are limited by the small sample and the action research context. Because data were gathered to inform our action research with Kyrie and Sara, we were not in a position to set up a control group, nor to gather data that would allow us to compare students' wiki revisions to those that they tended to make to their independent writing or small group writing in non-wiki settings. Additionally, we did not have the opportunity to observe students' collaborative writing in non-wiki settings to make comparisons with this wiki setting. However, the significant differences found in comparisons of types and levels of revisions, and of individual students' contributions to the wiki writing, lead us to believe that our research offers emerging insights into middle grades students' revision and participation behavior in wiki settings. Our discussion of 
the results and implications for teaching takes the form of responses to the three research questions.

\section{Wiki Task Fostered Frequent Revisions}

Kyrie's and Sara's assigned wiki task of reading for information, taking notes and writing essays, took place over an eight-week period. During this time, students took advantage of the affordances of the technology by making many revisions: replacing, adding, deleting and moving words, phrases, clauses, and sentences in their collaboratively-composed research essays. In this respect, the students' revision behaviour was consistent with that of students in studies of revision practices in middlegrades (e.g., Mak \& Conium, 2008; Woo, Chu \& Li, 2013) as well as postsecondary classrooms (e.g., Kessler, 2009). Unlike students in previous research (Lee, 2010; Karasavvidis, 2010; Mak \& Conium, 2008), our study's middle grades students replaced and deleted information, although deletion was often not as common a revision practice as were replacing and adding information. Furthermore, and again unlike students in previous research (Lee, 2010; Karasavvidis, 2010), students in our study changed others' writing and accepted revisions to their contributions in order to improve the quality of the collaboratively composed essay.

Kyrie and Sara's wiki-writing context appears to have supported the revision practices. In addition to ensuring that the students' writing processes were facilitated by the computer affordances, the two teachers gave their students extended periods of time for writing and revising, a practice that is well supported by research for encouraging students' revisions and improvement of their writing (Pritchard \& Honeycutt, 2007; Witte, 2013). Additionally, students wrote collaboratively as a group during school time, another practice supported by research (e.g., Boscolo \& Ascorti, 2004). There was an ethos of working together to create a written composition for which all group members would be proud. The online tools connected home and school writing, so the sense of collaboration continued beyond the school day. In one wiki group, where one girl was the only independent contributor, we found out that she was not present during the group time in class because she attended a remedial language arts class. While the other group members collaborated side-by-side for their writing contributions, her means to collaborate was through independent contributions from home. The wiki environment made it possible for this student to contribute to the group project and have access to the work done by her group during times when she could not be present. She was also able to participate in whole class and small group discussions about the project during social studies periods.

\section{Revisions were Most Frequently Replacements of Words}

The students' revisions of their collaboratively written essays tended to be at the word level. This revision pattern is associated with novice writers (Sharple, 1999) and is considered to be less effective than revisions at the sentence, paragraph and whole-text levels in terms of improving the overall writing (MacArthur, 2007). To encourage more substantive revisions, teachers might devote more time to teaching writing and revision (Dinkins, 2014; Witte, 2013) during the social studies unit or consider bringing the social studies topics into the writing workshop lessons, thus integrating writing and other areas 
of the curriculum. In addition to teaching mini-lessons focusing on words (e.g., Kyrie and Sara demonstrated how to link sentences through the use of adverbial phrases, such as "in addition," "furthermore," or "secondly"), teachers might model thinking processes and provide self-questioning guides to support students in considering the text as a whole, as well as individual words and sentences, when revising (Chanquoy, 2009). The grade 5 and 6 students demonstrated that they were willing to make changes to each others' writing and clearly indicated that they shared a common purpose of co-learning and codeveloping stronger writing. Further instruction in writing and revision would likely be brought into their online and in-class collaborations and serve to strengthen the roles they played in their own learning and that of their peers (AMLE, 2010).

In our meetings with Kyrie and Sara, they mentioned the importance of lessons based on formative assessments, to support student writing and social studies learning. They told us that they were monitoring the wiki activity each day and would frequently bring individual wiki groups to the class meeting area to discuss positive behaviours or concerns around collaboration, as well as the direction of the research. When students write over an extended period of time, as did Kyrie and Sara's students, teachers have ample time to do ongoing formative assessment of both the students' wiki writing and the content understandings that they communicate in their writing. Teachers could use this assessment information to shape instruction, including the mini-lessons described above that we observed in Kyrie and Sara's classes, and to meet the needs of individual students.

Teachers' ongoing feedback arising from the assessment could involve discussing with students how their writing expresses larger ideas. Teachers could also engage students in thinking critically about the relationships between ideas within and across paragraphs, so that the students' focus is on more substantive meaning and communicative issues in the essays, rather than on individual words.

\section{Collaboration Took Place at School but Independent Contributions were Unevenly Distributed among Group Members}

The wiki setup in the two middle grades classrooms provided opportunities for all the students to be engaged, but also allowed for the social loafing that was identified in previous research conducted in undergraduate classrooms (Elgort, Smith \& Toland, 2008; Karassavvidis, 2010). In every wiki group, one student contributed significantly more frequently than any other group member and in some wiki groups, that student contributed independently from home more frequently than the group did together during class time. This inequality occurred even when provided the opportunity to learn in small groups (noted as atypical by Pianta et al., 2007), whose members had all expressed a desire to explore the same social concern in their research and writing. These inequities were also present in spite of a number of task features that research shows help to deter social loafing (Piezon \& Donaldson, 2005). In our study, task interdependence among group members was a feature, as the final research paper was dependent on the successful completion of the task by all group members. Individual contributions were visible to fellow wiki group members, as well as to teachers, and the students used the chat function of the wiki to encourage or cajole less active peers to contribute more. Additionally, the small group work during school hours helped to create group cohesiveness. The class 
time for small groups to work on the wikis did ensure that all students contributed in some way to the wiki content, even if it was only to type what peers directed them to type, or to read information from a website that could be used in a note typed in by a peer.

In summary, our research showed that the wiki setting established by Kyrie and Sara in their action research, showed their interests and desires to engage their students in "active, purposeful learning" in a curriculum that is "challenging, exploratory, integrative and relevant" (AMLE, 2010, no page). The wiki environment fostered middle grades students' revisions of their own, the group's and others' writing, though the revisions often remained at a superficial level. There is a need for greater teacher intervention to support students' writing processes, as well as their technical skills in navigating the wiki. Additionally, the imbalance of contributions among wiki group members in their independent at-home contributions reflects a need to build in participation structures to ensure that students tap into the collaborative potential of wikis.

\section{Acknowledgements}

We wish to thank the teachers and students who participated in this research project and the Social Science and Humanities Research Council of Canada, which funded the research.

\section{References}

Allal, L., \& Chanquoy, L. (2004). Introduction: Revision revisited. In L. Allal, L. Chanqouy, \& P. Largy (Eds.), Studies in writing: Vol. 13. Revision: Cognitive and instructional processes, (pp. 1-7). Boston, MA: Kluwer.

Association for Middle Level Education (AMLE). (2010). This we believe: Keys to educating young adolescents. Westerville, $\mathrm{OH}$ : Author. Retrieved from http://www.amle.org/aboutamle/thiswebelieve/tabid/121/default.aspx\#122516the-16-characteristics

Boscolo, P., \& Ascorti, K. (2004). Effects of collaborative revision on children's ability to write understandable narrative texts. In L. Allal, L. Chanqouy, \& P. Largy (Eds.), Studies in writing: Vol. 13. Revision: Cognitive and instructional processes, (pp.157-70). Boston, MA: Kluwer.

Capobianco, B. M. (2007). A self-study of the role of technology in promoting reflection and inquiry-based science teaching. Journal of Science Teacher Education, 18(2), 271-296.

Chanquoy, L. (2009). Revision processes. In R. Beard, D. Myhill, J. Riley, \& M. Nystrand (Eds.), Sage handbook of writing development (pp. 80-97): London, UK: Sage.

Coiro, J., Knobel. M., Lankshear, C., \& Leu, D. J. (2008). Central issues in new literacies and new literacies research. In J. Coiro, M. Knobel, C. Lankshear, \& D. J. Leu. (Eds.), Handbook of Research on New Literacies (pp. 1-21). London: Routledge.

Dinkins, E. G. (2014). Middle school students' perspectives of and responses to strategic revision instruction. Middle Grades Research Journal, 9(2), 75-90. 
Doult, W., \& Walker, S. A. (2014). 'He's gone and wrote over it': The use of wikis for collaborative report writing in a primary school classroom. Education 3-13, 42(6), 601-620.

Elgort, I., Smith. A.G., \& Toland, J. (2008). Is wiki an effective platform for group course work? Australasian Journal of Educational Technology, 24(2), 195-210.

Fitzgerald, J. (1987). Research on revision in writing. Review of Educational Research, 57(4), 481-506.

Fredricks, J. A., Blumenfeld, P. C., \& Paris, A. H. (2004). School engagement: Potential of the concept, state of the evidence. Review of Educational Research, 74(1), 59109.

Haythornthwaite, C. (2006). Facilitating collaboration in online learning. JALN, 10, 1-24. Retrieved on June 10, 2013 at http://sloanconsortium.org/jaln/v10n1/facilitatingcollaboration-online-learning

Hughes, J. E., \& Narayan, R. (2009). Collaboration and learning with wikis in postsecondary classrooms. Journal of Interactive Online Learning, 8(1), 63-82.

Jackson, J. M., \& Harkins, S.G. (1985). Equity in effort: An explanation of the social loafing effect. Journal of Personality and Social Psychology, 49(5), 1199-1206.

Johnson, D. W., \& Johnson, R. T. (1989). Cooperation and competition: Theory and research. Edina, MN: Interaction Book Co.

Johnson, D. W., \& Johnson, R. T. (2009). An educational psychology success story: Social interdependence theory and cooperative learning. Educational Researcher, 38(5), 365-379.

Jones, R. H. (2008). Patterns of revision in online writing: A study of Wikipedia's featured articles. Written Communication, 25(2), 262-289.

Karasavvidis, I. (2010). Wiki uses in higher education: Exploring barriers to successful implementation. Interactive Learning Environments, 18(3), 219-231.

Kemmis, S., \& McTaggart, R. (1988). The action research planner, $3^{\text {rd }}$ ed. Geelong, Victoria: Deakin University Press.

Kessler, G. (2009). Student-initiated attention to form in Wiki-based collaborative writing. Language Learning and Technology, 13(1), 70-95.

Kost, C. (2011). Investigating writing strategies and revision behavior in collaborative wiki projects. CALICO Journal, 28(3), 606-620.

Lankshear, C., \& Knobel, M. (2011). New literacies: Everyday practices \& classroom learning (2nd ed.). Maidenhead, UK: Open University Press.

Lee, L. (2010). Exploring wiki-mediated collaborative writing: A case study in an elementary Spanish course. CALICO Journal, 27(2), 260-276.

Lee, L. (2012). “A learning journey for all”: American elementary teachers' use of classroom wikis. Journal of Interactive Online Learning, 11(3), 90-102.

Leu, D. J., Kinzer, C. K., Coiro, J., Castek, J., \& Henry, L. A. (2013). New literacies: A dual-level theory of the changing nature of literacy, instruction, and assessment. In D. E. Alvermann, N. J. Unrau, \& R. B. Ruddell (Eds.), Theoretical models and processes of reading (6th ed.), (pp.1150-1180). Newark, DE: International Reading Association.

Leuf, B., \& Cunningham, W. (2001). The Wiki way: Quick collaboration on the Web. Boston, MA: Addison Wesley. 
MacArthur, C. A. (2007). Best practices in teaching evaluation and revision. In S. Graham, C.A. MacArthur, \& J. Fitzgerald (Eds.), Best practices in writing instruction, (pp. 141-162). New York: Guilford.

MacArthur, C. A., Graham, S., \& Harris, K. (2004). Insights from instructional research on revision with struggling writers. In L. Allal, L. Chanqouy, \& P. Largy (Eds.), Studies in writing: Vol. 13. Revision: Cognitive and instructional processes, (pp.125-155). Boston: Kluwer.

McHatton, P. A., Farmer, L. J., \& Bessette, H. J. (2014). Investigating middle school students' perceptions of their learning environments through drawings. Middle Grades Research Journal, 9(2), 37-55.

Mak, B., \& Coniam, D. (2008). Using wikis to enhance and develop writing skills among secondary school students in Hong Kong. System, 36, 437-455.

Meishar-Tal, H., \& Gorsky, P. (2010). Wikis: what students do and do not do when writing collaboratively. Open Learning, 25(1), 25-35.

Nicol, D., Littlejohn, A., \& Grierson, H. (2005). The importance of structuring information and resources within shared workspaces during collaborative design learning. Open Learning, 20(1), 31-49.

Pianta, R. C., Belsky, J., Houts, R., Morrison, F., \& The National Institute of Child Health and Human Development Early Child Care Research Network. (2007). Opportunities to learn in America's elementary classrooms. Science, 315(5820), 1795-1796. Retrieved from http://www.ncbi.nlm.nih.gov/pmc/articles/PMC2137172/

Piezon, S. L., \& Donaldson, R. L. (2005). Online groups and social loafing: Understanding student-group interactions. Online Journal of Distance Learning Administration, 8(4). Retrieved June 12, 2013 from: http://www.westga.edu/ distance/ojdla/winter84/piezon84.htm

Pifarré, M., \& Fisher, R. (2011). Breaking up the writing process: How wikis can support understanding the composition and revision strategies of young writers. Language and Education 25(5), 451-466.

Pritchard, R. J., \& Honeycutt, R. L. (2007). Best practices in implementing a process approach to teaching writing. In S. Graham, C.A. MacArthur, \& J. Fitzgerald (Eds.), Best practices in writing instruction, (pp. 28-49). New York: Guilford.

Rijlaarsdam, G., Couzijn, M., \& Van den Bergh, H. (2004). The study of revision as a writing process and as a learn-to-write process. Two prospective research agendas. In L. Allal, L. Chanqouy, \& P. Largy (Eds.), Studies in writing: Vol. 13. Revision: Cognitive and instructional processes, (pp. 189-207). Boston, MA: Kluwer.

Sharple, M. (1999). How we write: Writing as creative design. London: Routledge.

Slavin, R. E. (1996). Research on cooperative learning and achievement: What we know, what we need to know. Contemporary Educational Psychology, 21(1), 43-69.

Wichmann, A., \& Rummel, N. (2013). Improving revision in wiki-based writing: Coordination pays off. Computers \& Education, 62, 262-270.

Witte, S. (2013). Preaching what we practice: A study of revision. Journal of Curriculum and Instruction, 6(2), 33-59. 
Woo, M. M., Chu, S. K. W., \& Li, X. (2013). Peer-feedback and revision process in a wiki mediated collaborative writing. Education Technology Research and Development 61(2), 279-309.

Author Biographies

Christine Portier is a Postdoctoral Research Fellow and Course Instructor in the Department of Curriculum, Teaching and Learning at the Ontario Institute for Studies in Education, University of Toronto.

Shelley Stagg Peterson is a Professor in the Department of Curriculum, Teaching and Learning at the Ontario Institute for Studies in Education, University of Toronto. 